Gontar, N.N. (2021). The peculiarity of the problems of Russian administrative jurisdiction at the present stage of the legal system development. Management as a science of complex development. Collection of Scientific Articles. European Scientific e-Journal, 6 (12), 57-70. Hlučín-Bobrovníky: “Anisiia Tomanek” OSVČ. Гонтарь, Н.Н. (2021). Особенность проблематики российской административной юрисдикции на современном этапе развития правовой системы. Management as a science of complex development. Collection of Scientific Articles. European Scientific e-Journal, 6 (12), 57-70. Hlučín-Bobrovníky: "Anisiia Tomanek" OSVČ.

DOI: 10.47451 /jur2021-05-001

EOI: $10.11244 /$ jur2021-05-001

The paper is published in Crossref, Internet Archive, Google Scholar, Academic Resource Index ResearchBib, JGate, ISI, CiteFactor, ICI, eLibrary databases.

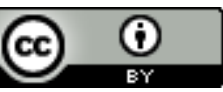

Nina N. Gontar

Associate Professor

Candidate of Sciences in Jurisprudence (PhD)

Department of State and Municipal Administration

North-West Institute of Management

The Russian Presidential Academy of National Economy and Public Administration

St Petersburg, Russia

E-mail: ninagontar@mail.ru

\title{
The peculiarity of the problems of Russian administrative jurisdiction at the present stage of the legal system development
}

\section{Abstract:}

This article discusses the results of the study of the problems of administrative jurisdiction in the Russian legal field at the present stage of its development. The object of the study was the administrative jurisdiction of the Russian Federation. The purpose of the study was to determine the complex problems of administrative jurisdiction of the Russian Federation at the current stage of development of the legal system. To solve the tasks set and achieve the research goal, historical, comparative and logical methods of analyzing the material and the results of individual stages of the study were used. The study used materials from leading Russian experts in the field of administrative jurisdiction, such as V.A. Zyuzin, B.A. Strashun, O.V. Krivelskaya, A.S. Nazarova and others, as well as legislative documents, including the Constitution of the Russian Federation and the Code of Administrative Procedure of the Russian Federation. As a result of the study, four main problems of the Russian administrative jurisdiction were identified and justified.

\section{Keywords:}

administrative jurisdiction, legal field, administrative law, administrative proceedings, Russian Federation.

Нина Николаевна Гонтарь

Аоцент, кандидат юридических наук Кафедра государственного и муниципацьного управ ения Северо-Западный институт управления Российская Академия народного хозяйства и государственной службы 
Санкт-Петербург, Россия

E-mail: ninagontar@mail.ru

\title{
Особенность проблематики российской аАминистративной юрисаикции на современном этапе развития правовой системы
}

\begin{abstract}
Aннотачия:
В Аанной статье рассматриваются результаты исследования проблем административной юрисдикции в российском правовом поле на современном этапе его развития. Объектом исследования была административная юрисдикция Российской Федерации. Целью исследование было определение комплекса проблем административной юрисдикции Российской Федерации на современном этапе развития правовой системы. Аیя решения поставленных задач и достижения цели исследования были использованы исторический, сравнительны и могический методы анализа материала и результатов отдельных этапов исследования. В ходе исследования были использованы материалы ведущих российских специалистов в области административной юрисдикции, таких как В.А. Зюзина, Б.А. Страшуна, О.В. Кривельской, А.С. Назаровой и Аругих, а также законодательные документы, включая Конституцию Российской Федерации и Кодекс административного судопроизводства Российской Федерации. В результате исследования были определены и обоснованы четыре основных проблемы российской административной юрисдикции.
\end{abstract}

Ключевые слова:

аАминистративная юрисдикция, правовое поле, аАминистративное право, административное судопроизводство, Российская Федерация.

\section{Introduction}

The Constitution of the Russian Federation proclaims that "a person, his rights and freedoms are the highest value. The recognition, observance and protection of human and civil rights and freedoms is the duty of states" (the Constitution of the Russian Federation, Art. 2). To implement these tasks, all legal structures of the state, including the judiciary, are involved. Every Russian citizen has the right to apply to the courts to protect the rights, honour and dignity of the individual. "The Supreme Court of the Russian Federation is the highest judicial body for civil cases, settlement of economic disputes, criminal, administrative and other cases, subordinate courts of general jurisdiction and arbitration courts formed following the federal constitutional law and exercising judicial power through civil, arbitration, administrative and criminal proceedings..." (The Constitution of the Russian Federation, Art. 126).

In most cases, administrative jurisdiction is understood as competence in considering cases of a certain type and making decisions on them. However, it is 
noticed that many people understand this order and competence in their way. In the history of law, this order has also been changed repeatedly. In administrative law, administrative jurisdiction is considered not only as a law enforcement activity of courts and executive authorities to consider cases of administrative offences but also as an activity to consider and resolve disputes about the law in the field of public administration. At the same time, it should bear in mind that the jurisdiction itself can be called punitive only when a decision on punishment is made (Gridin, 2014).

However, it should also note that administrative jurisdiction cannot be reduced only to the consideration of administrative disputes by executive authorities. It should understand much more broadly. These authorities consider not only issues related to administrative disputes, but also those for which administrative responsibility does not occur. In this case, we are talking, for example, about preventive measures, preventive measures, measures of procedural support. All of them do not arise from administrative and legal disputes. They are used by various bodies based on their competence.

The area of issues related to administrative and procedural activities carried out by executive authorities is quite closely related to administrative jurisdiction. It is the reverse side of their activities, not related to the offence, i.e., with the jurisdictional process. Specialists refer to this type of products such as registration, licensing, adopting regulatory acts, complaints and appeals of citizens, and others.

The object of this study was the Russian administrative jurisdiction.

The purpose of the study was to determine the complex of Russian administrative jurisdiction problems at the current stage of development of the legal system.

Based on the purpose of the study, the tasks of its implementation were determined:

- characterize the administrative jurisdiction in the Russian legal field at the present stage of its development.

- $\quad$ analyze the continental and Anglo-Saxon models of administrative jurisdiction as a comparison of the most popular foreign models with the Russian one.

- identify the problems of administrative jurisdiction at the current stage of development of the Russian legal field.

To solve the tasks set and achieve the research goal, historical, comparative and logical methods of analyzing the material and the results of individual stages of the study were used. 
The study used materials from leading Russian experts in administrative jurisdiction, such as V.A. Zyuzin, B.A. Strashun, O.V. Krivelskaya, A.S. Nazarova and others, as well as legislative documents, including the Constitution of the Russian Federation and the Code of Administrative Procedure of the Russian Federation.

\section{Features of administrative jurisdiction in the Russian legal field}

Administrative jurisdiction is a rather specific branch of resolving a conflict or dispute of an administratively legal order. Among its most objective features in the Russian legal field is the fact that there is a need to implement an assessment between the parties of the legal side of the dispute, which will be the main one in ensuring fairness and legality of the decision. Another feature should be called the need to apply administrative or disciplinary measures to the guilty party. As a result of consideration of these features of the Russian administrative jurisdiction, it notes that this type of jurisdiction arises out of court and requires the disputes' resolution in a legal manner.

Below is a brief description of the types of administrative jurisdiction.

Disciplinary proceedings are a tool for applying disciplinary measures for committing various kinds of disciplinary offences, which are provided for by the Russian legislation. Applicable, e.g., to municipal employees, this is the improper performance of personally official duties. Disciplinary measures are usually imposed on the senior positions of the institution. Also, violation of the labour regulations in the institution is often referred to as disciplinary proceedings.

Complaints proceedings arise when a formal complaint is received by the relevant authorities about the illegal actions of the other party. When initiating a complaint, it is necessary to consider, study the documents and give a positive or negative response. The decision on this complaint must be sent to a citizen of the Russian Federation within a strictly established time frame. In the future, officials are obliged to carry out systematics, analysis and generalization of such information to establish the regularity and causes of a particular conflict situation. In case of dissatisfaction with the answer, a citizen has the right to apply to the judicial authorities. In case of an untimely response to such a complaint, disciplinary measures may be imposed on the official.

Enforcement proceedings provide for the adoption of solutions to problems through the judicial authorities by initiating enforcement proceedings with the forced withdrawal of funds or property in favour of the state.

Conciliation proceedings are a fairly new term in administrative jurisdiction and are not yet clearly regulated in the Russian theory of jurisprudence. 
It is also customary to distinguish five forms of administrative jurisdiction, of which four are listed below:

- proceedings in the jurisdiction body of the first instance, where the simplest cases are considered, which are conducted from the data of the protocol and is the most popular form in the Russian Federation;

- accelerated proceedings, applied if the offence is recognized as insignificant;

- $\quad$ special proceedings, which are used when considering cases that do not pose a danger to society, to replace criminal punishment with administrative;

- proceedings in the jurisdiction body of the second instance beginning if the decision on the case is appealed to a higher authority.

The main form of administrative jurisdiction is considered to be the application right, in which an important place is given to the penalties' application to violators of legal norms.

To understand the Russian legal system of administrative jurisdiction, it is also necessary to clearly define its functions. There are four main functions in the administrative jurisdiction:

1. The protective function consists of the state system protection, the rights and freedoms of society, the prevention of various offences, strict compliance with all the norms of the current legislation, and others. The security function is primarily connected through interaction with law enforcement agencies.

2. The educational function is to properly educate citizens and the whole society in proper behaviour and compliance with all legal norms. This function is manifested when solving administrative cases by the relevant authorities legally and in compliance with all ethical standards.

3. The regulatory function is manifested in the application of legal norms in practice.

4. The preventive function consists of carrying out measures by control bodies aimed at implementing measures to prevent offences (Kokosh, 2016).

All the above-listed functions of administrative jurisdiction are implemented using appropriate methods. When persuading, the most popular methods are conversations of an individual and collective nature, e.g., administrative, introductory, preventive or educational. In the coercion case, a direct impact is made on the object to achieve the set goals.

Administrative jurisdiction is divided into judicially administrative jurisdiction and administrative jurisdiction carried out administratively. The following principles of jurisdiction are distinguished: 
- Subordination. It means that all cases are considered under the jurisdiction of the authorized body and in no other way.

- Powers of attorney. This principle means that, e.g., a responsible official authorized to perform such a procedure following the law is engaged in drawing up a protocol.

- Legality. This principle is based on the regulatory legal acts in force on the Russian Federation territory. It establishes the lawful and lawful behaviour of all members of society.

- Publicity. All disputes should be considered openly, in the presence of all parties to the conflict. The only exception may be the fact that a person has announced the consideration of the case without his presence.

- The presumption of innocence. This principle means that a person is considered innocent until the decision, and sentence of the court comes into force. A citizen who is accused of a misdemeanour is not obliged to prove his innocence.

- Cost-effectiveness and efficiency. This principle is expressed in a fairly short period between the complaint receipt and its decision. It allows you to minimize the costs of this event.

- $\quad$ The right to protection. It means that the accused party has every right to get acquainted with all the case materials, involve a lawyer or an expert at the time of case consideration.

- Equality of citizens.

- Responsibility. It means that any official considering such disputes must make decisions following the law and in no other way (Kokosh, 2016).

The main subject providing administrative jurisdiction on the Russian Federation territory is the internal affairs bodies of the Russian Federation.

Thus, administrative jurisdiction in the Russian legal field has several pronounced features, based on which the typology, forms, methods and principles of its construction are built. A structured administrative jurisdiction is still undergoing a stage of evolution and final formation, which requires special attention to its fundamental differences from the most popular international models.

\section{Understanding of administrative jurisdiction in foreign countries}

The main distinguishing feature of many international models of administrative jurisdiction from the Russian one is that resolved through judicial authorities they take priority over the settlement of disputes out of court. These countries mainly 
include the countries of Western Europe and North America. In the Russian Federation, this practice is still in the formation process and has not been developed to the level of other countries.

The European jurisdiction has long formed the most popularly continental system of administrative justice in this region, of which Germany is a prominent representative. In Germany, the administrative justice's branch was born due to the creation of the Privy Council authorized to consider complaints and claims in 1819. It should note that the model for this system was the French Council of State, created in 1799 by Napoleon Bonaparte. Following the Regulation on Administrative Courts, adopted in 1960 (The Code of Administrative Court Procedure of the Federal Republic of Germany, 1960), the German administrative courts' system consists of three instances. The first instance is an administrative court with universal jurisdiction. It is followed by the Supreme Administrative Court of the land, which already acts as an appellate instance. At the top of this system is the Federal Administrative Court, which acts as a cassation instance. However, it can sometimes perform the functions of a court of the first instance. In addition to the three instances of administrative courts of general competence listed above, there are also courts of special competence.

Over the past 20 years, many amendments and additions have been made to the Regulation on Administrative Courts. However, this legal document remains a unique single act that regulates most of the parties to the organization and functioning of the administrative justice courts of the Federal Republic of Germany. This provision defines that the courts of administrative justice in Germany dealing exclusively with public law disputes: either between subjects of public law or between citizens and the administration. It should note that "the lion's share of these disputes are the requirements for the issuance of an administrative act necessary, in the opinion of the plaintiff, and the requirements for the cancellation or modification of an already existing administrative act that affects the rights or freedoms of the plaintiff" (Krivelskaya, 2004).

The administrative justice's model of the Federal Republic of Germany is distinguished by a huge number of normative acts, which, nevertheless, quite clearly regulate its activities. An example is several other legal documents, including the laws On Administrative Procedures, On Reducing the Courts' Burden in the Field of Administrative and Financial-Judicial Jurisdiction, On the New Regulation of Administrative-Judicial Process and many other normative legal acts. All these acts clearly describe the entire set of tools for the activities of administrative justice institutions. However, despite such positive features of the German administratively justice system, it has recently been 
subjected to harsh criticism in scientific circles. In particular, "it is proposed to switch to a two-level system for simplest cases and preserve three levels only for extremely important cases. It is dictated, first of all, by economic expediency, also by the need to unload ships and reduce the number of cases under consideration" (Krivelskaya, 2004).

The continental system of administrative justice gained popularity not only in Germany but also in France, Austria and several other major European countries, nevertheless, has not become popular in other parts of the world. Several major developed and developing countries of the world adhere to the principle of "unified justice". This principle implies that management acts are subject to control by courts of general jurisdiction.

The future Anglo-Saxon model of administrative justice originated in Great Britain at the beginning of the 20th century, becoming "a disappointment in the ways of considering administrative and legal disputes by ordinary judges". The emergence of the modern system of administrative tribunals is fundamentally associated with the adoption in 1911 of the law On National Insurance and the separate scheme establishment for filing complaints on these issues from the general courts (Sazhina, 1984). In the 21 st century, we can already talk about their independent organizational and legal status. It is explained by the cases' peculiarity under their jurisdiction disputes, derived from administratively legal relations. Although the tribunals in the UK are only judicial-like bodies, many experts note their 'judicial' nature. "This is a separate establishment of courts engaged in determining the rights and obligations of a special category. Just as in the old days there were church courts that dealt with property management cases, and the court of the Chancellor, which resolved custody issues, so today new tribunals have been formed that consider disputes between a citizen and the state" (Sazhina, 1984). This view is explained by the fact that the procedure of their jurisdictional activity is fundamentally similar to the process in general courts.

The Anglo-Saxon system of administrative justice is characterized by the subordination of administrative justice bodies to the general judicial system of the country. In particular, the general court performs both the review of decisions made by the Tribunals and control and supervisory functions concerning this type of bodies. According to professor B.A. Strashun, the courts of general jurisdiction in such a state "exercise direct control over the legality of administrative acts, in particular through court orders. For example, mandamus is a court order obliging an official to perform an action or issue an act within his competence; an injunction is 
a court order prohibiting an official from performing an action or issuing an act" (Strashun, 2000).

Thus, the concept of administrative justice has been developing in most developed countries, e.g., Western Europe and North America, for more than 100120 years. Today, administrative jurisdiction in the West has a much more developed structure and methodological apparatus. Consequently, the peculiarities of administrative justice in each country are significant and unique. However, it is possible to distinguish several of their common features that characterize this institution as a whole:

1) both systems of administrative justice are characterized by the attribution of disputes arising in the field of administrative management to its management;

2) in the systems, a body specially created and adapted to resolving disputes about the law is used as a jurisdictional body:

- in the continental model, the role of such a body is played by special administrative courts organized outside the system of administrative bodies and courts of general jurisdiction,

- in the Anglo-Saxon model, departmental court-like institutions act as jurisdictional bodies, subordinate to the general court and resolving disputes only within their department;

3) each system of administrative justice assumes consideration and resolution of administrative disputes in the procedural form established by law (Bezruchenkov, 2015).

\section{Administrative jurisdiction's problems at the present stage of the Russian Federation's legal field development}

Since 2015, the concept of administrative jurisdiction has been legally consolidated (The Code of Administrative Procedure of the Russian Federation, 2015). However, in the legal literature since the Soviet period, the concepts of ‘jurisdiction' and 'administrative jurisdiction' have always been given considerable attention. The concept of 'jurisdiction' has various meanings, for example, jurisdiction, the jurisdiction of the cases being resolved, the authority to resolve cases and apply sanctions. Noting the ambiguity of this term, the legal doctrine connects it with some activities' implementation of state bodies. For example, legal scholars engaged in the development of general theoretical problems of law define jurisdiction as "the activity of competent authorities authorized to consider legal cases and make legally binding decisions on them" (Grechkina, 2014). 
After the adoption of the Code, the administrative jurisdiction has already adopted a clearer terminological outline: “...the procedure for conducting administrative proceedings when the Supreme Court of the Russian Federation, courts of general jurisdiction, magistrates (...) consider and resolve administrative cases on the protection of violated or disputed rights, freedoms and legitimate interests of citizens, rights and legitimate interests of organizations, as well as other administrative cases, arising from administrative and other public legal relations and related to the exercise of judicial control over the legality and validity of the exercise of state or other public powers" (The Code of Administrative Procedure of the Russian Federation, Art. 1, par. 1).

At the same time, it should note that, in theory, the issue of the administrative and judicial jurisdiction ratio remains relevant to this day. There is an opinion that administrative jurisdiction should be considered as a type of administrativeprocedural activity carried out in out-of-court or judicial proceedings to consider and resolve administrative-legal disputes and applying administrative-coercive measures.

According to A.S. Nazarova, the most pronounced problem of administrative jurisdiction is the incompleteness of the formation of courts of administrative jurisdiction. According to Chapter 23 of the Code of Administrative Offenses of the Russian Federation, "Judges, bodies, officials authorized to consider cases of administration offences", the legislator lists all bodies and officials, who officially consider cases of administrative offences, including judges, and Article 23.1 lists the elements of offences that judges consider (Nazarova, 2019).

However, it should note that numerous cases of administrative offences are considered by bodies and officials who themselves draw up protocols on administrative offences. In turn, it violates the principle of equality and competitiveness of the parties when resolving a dispute within the framework of the legislation on administrative offences. A.S. Nazarova suggests transferring the consideration of such disputes to the jurisdiction of courts of various levels, which will ensure more effective and fair consideration of cases of administrative offences (Nazarova, 2019).

The weak evolution of administrative jurisdiction towards the improvement of some areas of administrative law can also note as a problem. Several compositions require special knowledge, and, accordingly, high qualification of judges and a more structured specialization in various compositions of administrative offences. That is why, taking into account the complexity of the formation of such judges' compositions, numerous administrative offences are considered by specially authorized bodies. 
Currently, local attempts to resolve these problems are being reviewed. In several courts of general jurisdiction, there is already a division of judges by specialization: criminal cases, civil cases, cases within the framework of administrative proceedings. However, such a division exists, as mentioned above, locally and requires further creation of clear regulations and tools for implementation, development and adjustment.

Another problem remains the existing legal illiteracy or extremely weak literacy of the population in legislation on administrative offences. It can observe that the percentage of cases defended by defendants or plaintiffs, conducted independently, remains extremely small. Also, the percentage of refusals to consider administrative court cases due to inconsistencies in the documentation or claims filed in the claim is still high. In this case, the bodies of administrative jurisdiction should also be entrusted with an educational and preventive function, namely, carrying out measures to eliminate illiteracy in administration responsibility, especially in educational institutions.

Thus, in the course of the study, several characteristic problems of administrative jurisdiction at the current stage of development of the Russian Federation's legal field were identified:

1. The ratio of administrative and judicial jurisdiction.

2. The incompleteness of the formation of courts of administrative jurisdiction.

3. Weak evolution of administrative jurisdiction towards the improvement of certain areas of administrative law.

4. Legal illiteracy or extremely weak literacy of the population in legislation on administrative offences.

\section{Discussion}

Today, the analysis of administrative jurisdiction remains relevant at the current stage of the evolution of the Russian legal field. In the study course, four main problems of modern Russian administrative jurisdiction were identified and justified. In this regard, the directions of further research, which are proposed for work, were identified:

1. Determination of the administrative and judicial jurisdiction ratio, taking into account the administrative jurisdiction concept as a type of administrativeprocedural activity, carried out in out-of-court or judicial proceedings to consider and resolve administrative and legal disputes and applying administrative and coercive measures. 
2. Creation of methods for improving the legal literacy of the population in legislation on administrative offences.

\section{Conclusion}

The purpose of this study was to determine the complex problems of the Russian administrative jurisdiction at the current stage of development of the legal system, which was achieved and presented in the conclusions of the paragraphs of this article.

Administrative jurisdiction in the Russian legal field has several pronounced features, based on which the typology, forms, methods and principles of its construction are built. A structured administrative jurisdiction is still undergoing a stage of evolution and final formation, which requires special attention to its fundamental differences from the most popular international models. The concept of administrative justice has been developing in most developed countries, e.g., Western Europe and North America, unlike the Russian Federation, for more than 100-120 years. Today, administrative jurisdiction in the West has a much more developed structure and methodological apparatus. Consequently, the peculiarities of administrative justice in each country are significant and unique. The study identified four characteristic problems of administrative jurisdiction at the current stage of development of the Russian legal field, which needs to be analyzed and developed ways to solve them.

\section{References:}

Bezruchenkov, M. V. (2015). Administrative justice in foreign countries. Politics, State and Law, 2. Retrieved February 11, 2021, from https://politika.snauka.ru/2015/02/2330 (in Russian)

Demin, A.A. (2004). Problems of methods of legal regulation. Administrative Law and Administrative Process: actual Problems, 104-127. Moscow: Jurist. (in Russian)

Grechkina, O.V. (2014, February 19). Administrative judicial jurisdiction: current state and prospects of development. Administrative Justice and administrative jurisdiction: questions of theory and practice: materials of the 7 th International Scientific and Practical Conference dedicated to the memory of Yuri Markovich Kozlov, 19-24. Moscow: Publishing Center of the O.E. Kutafin University. (in Russian)

Gridin, S.I. (2014). Administrative jurisdiction in Russian law. Proceedings on cases of administrative offenses. The vector of legal science. Bulletin of the O.E. Kutafin University, 2, 74-79. Moscow. (in Russian) 
Knyazeva, I.N. (2011). Resolution of some issues of jurisdiction in the proceedings on cases of administrative offenses. Administrative Law and Process, 12, 28-31. (in Russian)

Kokosh, E. (2016, December 16). Administrative jurisdiction. Bank Reference. Retrieved February 15, 2021, from https://bankspravka.ru/bankovskiyslovar/administrativnaya-yurisdiktsiya.html (in Russian)

Krivelskaya, O.V. (2014). Administrative Justice in the Federal Republic of Germany: dissertation... Candidate of Legal Sciences: 12.00.14. Moscow: Moscow State Institute of International Relations. (in Russian)

Nazarova, A.S. (2019, November) Actual problems of administrative jurisdiction in the Russian Federation. Research of young scientists: materials of the 4th International Scientific Conference, 40-42. Kazan: Young scientist. Retrieved February 5, 2021, from https://moluch.ru/conf/stud/archive/350/15405/ (in Russian)

Sazhina, V.V. (1984). Administrative Justice of Great Britain: dissertation... Candidate of Legal Sciences: 12.00.02. Moscow: Institute of State and Law of the USSR Academy of Sciences. (in Russian)

Slepchenko, V. A. (2020). Some aspects of administrative justice in foreign countries and Russia. Issues of Russian Justice, 5, 250-261. Yekaterinburg: Ural State Law University. (in Russian)

Strashun, B.A. (2000). Constitutional (state) law of foreign countries. The general part. Moscow. (in Russian)

The Code of Administrative Court Procedure of the Federal Republic of Germany of January 21, 1960. Retrieved February 25, 2021, from http://www.gesetzeim-internet.de/englisch_vwgo/index.html

The Code of Administrative Legal Proceedings of the Russian Federation, No. 21 FZ of March 08, 2015, as amended on April 30, 2021. (in Russian)

The Code of Administrative Procedure of the Federal Republic of Germany. Retrieved February 21, 2021, from https://germanlawarchive.iuscomp.org/?p=292

The Code of the Russian Federation on Administrative Offenses, No. 195-FZ of December 30, 2001 (ed. 11.06.2021). (in Russian)

The Constitution of the Russian Federation of 1993, as amended on July 1, 2020. (in Russian)

The Law of the Russian Federation "On Appeal to the Court of Actions and Decisions Violating the Rights and Freedoms of Citizens", No. 4866-1 of April 27, 1993. Vedomosti of the Congress of People's Deputies of the Russian 
Federation and the Supreme Court of the Russian Federation. 1993. No. 19. (in Russian)

The UK Tribunals, Courts and Enforcement Act 2007. Retrieved February 20, 2021, from http://www.legislation.gov.uk/ukpga/2007/15/contents

Zyuzin, V.A. (2020). Administrative justice and jurisdiction in foreign countries: A textbook. Moscow: Russian State University of Justice. (in Russian) 